\title{
KAJIAN DEKONSTRUKSI DERRIDA DALAM NOVEL SENGSARA MEMBAWA NIKMAT KARYA SUTAN SATI
}

\author{
Andi Sutisno \\ Program Studi Pendidikan Bahasa Indonesia \\ Universitas Swadaya Gunung Jati Cirebon \\ e-mail: aksaraabdikata@gmail.com
}

\begin{abstract}
ABSTRAK
Penelitian ini bertujuan untuk membantah anggapan yang selama ini dianggap benar. Dengan bukti-bukti yang ada pada teks novel Sengsara Membawa Nikmat. Penelitian ini ingin membuktikan bahwa tokoh protagonis tidak selalu benar, dan sebaliknya tokoh atagonis juga tidak selamanya salah. Penulis ingin mengungkap sisi lain dari tokoh-tokoh yang ada dalam cerita Sengsara Membawa Nikmat. Dengan pemunculan sisi lain tersebut, diharapkan pembaca tidak hanya terkungkung pada satu makna yang selama ini mendominasi pemahaman dan dianggap sebagai kebenaran mutlak di kalangan pembaca.

Metode yang digunakan dalam penelitian ini adalah deskriptif kualitatif. Penelitian ini menggunakan metode dan teknik analisis teks untuk memahami karakter setiap tokoh yang ada dalam cerita sengsara membawa nikmat. Penelitian ini menggunakan teori Dekonstruksi yang digagas oleh Jacques Derrida, dan Strukturalisme sebagai teori pendukung dalam menguraikan watak tokoh.

Pengkajian secara dekonstruksi telah melebur batas yang selama ini tercipta antara tokoh protagonis-antagonis dan tokoh utama-tambahan. Setiap tokoh adalah tokoh, tidak ada pertimbangan tokoh protagonis dan antagonis. Tokoh protagonis ternyata juga memiliki sisi negatif, dan sebaliknya tokoh antagonis ternyata juga memiliki sisi positif yang patut dicontoh. Dengan kata lain, tokoh dalam novel sengsara membawa nikmat juga seperti kita (manusia nyata) yang memiliki sifat baik dan buruk, kelebihan dan kekurangan.

Begitu juga dengan tokoh utama dan tokoh tambahan. Kita tidak bisa mengabaikan tokoh walaupun tokoh tersebut tidak selalu dimunculkan dalam cerita. Sekecil apapun peran tokoh dalam cerita ia tetap ikut membangun cerita tersebut. Jika salah satu tokoh dihilangkan akan muncul kemungkinan baru yang akan merubah jalan cerita. Kemungkinan baru juga akan muncul jika salah satu tokoh melakukan tindakan yang berbeda dari apa yang diceritakan.
\end{abstract}

\section{Kata Kunci: Sengsara Membawa Nikmat, Dekonstruksi Derrida.}

\section{PENDAHULUAN}

Manusia merupakan makhluk hidup paling sempurna yang terlahir dengan sikap dan pola perilaku yang berbeda satu sama lainnya. Hal itu selalu kita jumpai dalam kehidupan sehari-hari. Perbedaan sikap dan perilaku tersebut dipengaruhi oleh banyak faktor, baik yang berasal dari dalam diri manusia itu maupun faktor dari luar. Pengaruh-pengaruh itu menjadikan manusia sebagai makhluk yang dinamis. Dalam keadaan tertentu, perilaku manusia dapat berubah sesuai dengan situasi dan kondisi yang sedang dihadapinya.

Karya sastra adalah hasil kreativitas manusia yang objeknya adalah manusia dan kehidupan. Kreativitas sastrawan dalam menemukan dan memilih suatu peristiwa atau kejadian untuk dijadikan bahan dan tema karyanya dapat berupa pengalaman yang diolah secara estetis sehingga menghasilkan karya baik berupa prosa atau 
puisi. Sastra merupakan refleksi dari pengalaman hidup pengarangnya. Pengalaman hidup tersebut bisa berwujud pengalaman pengarang sendiri dan pengalaman orang lain yang telah melalui perenungan, penghayatan, dan penjiwaan sehingga menjadi nilai-nilai yang bermakna bagi kehidupan manusia. Berdasarkan paparan di atas dapat pula dikatakan bahwa sastra merupakan cerminan budaya pada saat karya sastra itu dibuat. Oleh karena itu, perkembangan kebudayaan suatu bangsa dapat dipelajari dari karya sastra yang dihasilkan. Jadi, karya sastra tidak dapat dipandang sebagai hasil karya seni yang sempit, tetapi harus dipandang sebagai hasil budaya yang memiliki dimensi luas.

Karya sastra diciptakan untuk dapat dibaca, dinikmati, dan dipahami sehingga bisa bermanfaat dalam kehidupan masyarakat. Melalui karya sastra pengarang berusaha untuk menyampaikan pesan-pesan tertentu kepada pembaca.

Salah satu sarana untuk menyampaikan pesan tersebut adalah melalui tokoh dalam

cerita. Tokoh adalah individu rekaan yang mengalami peristiwa atau tindakan di

dalam berbagai peristiwa cerita (Sudjiman, 1991:16). Tokoh pada umumnya berwujud manusia dan kadang-kadang juga berwujud binatang, tumbuhan (dalam

cerita fabel), serta benda mati yang dihidupkan.

Pemaknaan karya sastra sangat bervariasi. Biasanya pengarang berusaha menuntun pembaca untuk memaknai sebuah karya sesuai dengan harapan pengarang. Namun, dalam beberapa karya, pembaca diharapkan untuk menerka dan meyimpulkan makna karya sastra sesuai dengan pemahamannya masing-masing.

Tidak ada jaminan bahwa pembaca akan mampu menangkap makna dalam karya sastra sesuai harapan pengarang. Tetapi, akan selalu muncul satu makna dominan yang berkembang di kalangan pembaca. Makna dominan tersebut dipengaruhi oleh konsep pemikiran barat yang bersifat logosentris, melalui oposisi biner yang menyatakan satu hal lebih baik dari yang lain. Hal ini membuat pembaca cenderung mempercayai satu makna dominan sebagi kebenaran mutlak, sehingga mereka tidak melihat atau menilai karya sastra secara objektif dengan penilaian dua arah melalui dua perspektif yang berbeda.

Pemaknaan tunggal ini terjadi pada sebagian besar karya sastra. Salah satunya pada novel Sengsara Membawa Nikmat karya tulis Sutan Sati yang diterbitkan oleh Balai Pustaka. Novel ini merupakan salah satu novel yang terbilang sukses di eranya.

Novel ini menceritakan tentang kehidupan Midun yang penuh cobaan dan masalah. Masalah itu tak lain datang dari seorang kemenakan penguasa di kampungnya yaitu Kacak. Kacak sangat membenci Midun karena keelokan rupa dan tingkah lakunya. Kacak berharap orangorang dapat menyukai dirinya seperti mereka menyukai Midun. Namun karena sikap Kacak yang begitu kurang ajar, masyarakat kampung tersebut malah membenci Kacak. Hal ini membuat Kacak menjadi iri dan dendam kepada Midun, sehingga tak hentihentinya ia mencoba mencelakakan Midun. Dengan kesabaran dan kesungguhan hatinya, akhirnya Midun bisa keluar dari masalahnya dan memperoleh kehidupan yang lebih baik. Pada akhirnya Midun mendapatkan semua kebahagiaan sebagai buah dari kesabaran, kerja keras, dan kejujuran yang ia miliki selama ini. Sementara Kacak justru ditangkap polisi karena menyalahgunakan jabatannya. Konflik yang terjadi antara Midun sebagai tokoh protagonis dan Kacak sebagai tokoh antagonis berikut tokoh-tokoh yang mendukung kedua belah pihak secara langsung telah mengkotak-kotakan karakter masing-masing tokoh. Semua sifat yang baik ditemukan pada tokoh protagonis, sementara tokoh antagonis diidentikkan dengan sifatsifat yang tidak baik.

Penelitian yang akan bertujuan untuk membantah anggapan yang selama ini dianggap benar. Dengan bukti-bukti yang ada pada teks novel Sengsara Membawa Nikmat penelitian ingin membuktikan bahwa tokoh protagonis tidak selalu benar, dan sebaliknya tokoh atagonis juga tidak 
selamanya salah. Penulis ingin mengungkap sisi lain dari tokoh-tokoh yang ada dalam cerita Sengsara Membawa Nikmat. Dengan pemunculan sisi lain tersebut, diharapkan pembaca tidak hanya terkungkung pada satu makna yang selama ini mendominasi pemahaman dan dianggap sebagai kebenaran mutlak di kalangan pembaca.

\section{KAJIAN TEORI \\ Dekonstruksi Derrida}

Dekonstruksi identik dengan resepsi sastra. Apabila teks dikaitkan dengan perempuan dan masalah-masalah kolonial, maka dekonstruksi identik dengan feminis dan postkolonial. Apabila teks dikaitkan dengan cerita dan penceritaan, dekonstruki identik dengan naratologi dan postrukturalis. Dengan demikian postrukturalisme adalah mendekonstruksi kekuatan laten subjek kultural, subjek-subjek hegemonis yang secara terus menerus mengkondisikan situasi marginalitas. 'perempuan ' adalah simbol marginalitas yang paling konstan. Perempuan adalah manifestasi hawa ditaman eden, kaum buruh dan tani bagi kelompok marxis, pribumi dalam pandangan kolonial, ekonomi lemah dalam kaitannya dengan proyek kapitalis, novel populer dalam kerangka sastra yang indah (kesusastraaan), pada tradisional dalam era swalayan, dan sebagainya. Pada dasarnya dekostruksi diperhadapkan pada simbol-simbol 'perempuan' seperti diatas.

Dalam bidang filsafat maupun sastra, dekonstruksi termasuk salah satu teori yang sangat sulit untuk dipahami. Dibandingkan dengan teori-teori postrukturalisme pada umumnya, secara definitif perbedaan sekaligus ciri khas dekonstruksi sebagaimana dikemukakan oleh Derrida (1976) adalah penolakannya terhadap logosentrisme dan fonosentrisme yang secara keseluruhan melahirkan oposisi biner dan cara-cara berpikir lainnya yang bersifat hierarkis dikotomis. Konsep dekontruksi (Selden, 1986:84) mulai dikenal sejak Derrida membawakan makalahnya yang berjudul "Structure, sign, and play in the discourse of the human sciences ",di universitas Johns Hopkins tahun 1966.

Secara leksikal prefiks 'de' berarti penurunan, pengurangan, penokohan, penolakan. Jadi, dekonstruksi dapat diartikan sebagai cara-cara pengurangan terhadap konstruksi, yaitu gagasan. Kristeva (1980:36-37), misalnya, menjelaskan bahwa dekonstruksi merupakan gabungan antara hakikat destruktif dan konstruktif. Dekonstruksi adalah cara membaca teks, sebagai strategi. Dekonstruksi tidak sematamata ditunjukkan terhadap tulisan, tetapi semua pernyataan kultural sebab keseluruhannya pernyataan tersebut adalah teks yang dengan sendirinya sudah mengandung nilai-nilai, prasyarat, ideologi, kebenaran, dan tujuan-tujuan tertentu. Dekonstruksi dengan demikian tidak terbatas hanya melibatkan diri dalam kajian wacana, baik lisan maupun tulisan, melainkan juga kekuatan-kekuatan lain yang secara efektif mentransformasikan hakikat wacana. Menurut Al-fayyadl (2011: 232) dekonstruksi adalah testimoni terbuka kepada mereka yang kalah, mereka yang terpinggirkan oleh stabilitas rezim bernama pengarang. Maka, sebuah dekonstruksi adalah gerak perjalanan menuju hidup itu sendiri.

Tokoh terpenting dekonstruksi adalah Jacques Derrida, seorang Yahudi Aljazair yang kemudian menjadi ahli filsafat dan kritik sastra di Perancis. Dekonstruksi dikembangkan atas dasar pemahaman sepihak tradisi kritik, yaitu yang sematamata memberikan perhatian terhadap ucapan. Aliran dekonsruksi lahir di Perancis sekitar tahun 1960-an, yang kemudian berpengaruh besar di Amerika sekitar tahun 1970-an hingga pada tahun 1980-an. Pada dasarnya, menurut Sarup (2003:51) dekonstruksi bertujuan untuk membongkar tradisi metafisika barat seperti fenomenologi Husserlian, strukturalisme Saussurean, strukturalisme Perancis pada umumnya, psikoanalisis Freudian dan Psikoanalisis Lacanian. Tugas dekonstruksi, mengungkap hakikat problematika wacana-wacana yang dipusatkan, dipihak yang lain membongkar 
metafisika dengan megubah batas-batasnya secara konseptual.

Pada dasarnya dekonstruksi yang sudah dilakukan oleh Nietzsche (Culler, 1983:86-87) dalam kaitannya dengan usahausaha untuk memberikan makna baru terhadap prinsip sebab-akibat. Prinsip sebabakibat selalu memberikan perhatian terhadap sebab, sedangkan akibatnya sebagai gejala minor. Nietzsche menjelaskan bahwa prinsip sebab akibat bukanlah hukum universal melainkan merupakan retorika bahasa, sebagai gejala metonimi, gejala bahasa dengan cara melekatkan nama orang atau benda-benda pada pusat objek yang lain.

Saussure menjelaskan bahwa makna yang diperoleh melalui pembagian lambanglambang menjadi penanda dan petanda. Dekonstruksi menolak keputusan tersebut dengan cara terus menerus berusaha melepaskan diri, sekligus mencoba menemukan pusat-pusat yang baru. Menurut Saussure (Eagleton, 1983:128), hubungan penanda dengan petanda bersifat pasti.

$$
\text { Derrida (Spivak, 1976:xliii) }
$$

menjelaskan peristiwa diatas dengan istilah differEnce dan differAnce, dua kata yang ucapannya hampir sama tetapi penulisannya berbeda, dibedakan melalui huruf ke-7. Kedua kata tersebut berasal dari bahasa latin, differe, yang sekaligus berarti to differ (membedakan) yang berkonotasi spasial, dan to defer (menuda) yang berkonotasi temporal. Derrida (Norris, 1983:32) menghubungkan kerangka ruang dan waktu dengan tanda dan bendanya, tanda sebagai wakil dari bendanya. Tanda sekaligus menunjukkan kehadiran yang tertunda. Makna kata difference berada dalam posisi yang mengambang antara to differ dan to defer, keduanya berpengaruh terhadap kekuatan tekstual, tetapi tidak secara utuh mewakili kata difference tersebut. Oleh karena tanda-tanda mengimplikasikan makna, maka makna karya pun selalu berbeda dan tertunda, sesuai dengan ruang dan waktu. Artinya, antara konsep dan kenyataan selalu mempunyai jarak sekaligus perbedaan. Derrida menjdai terkenal karena konsep dekonstruksi, logosentrisme, fonosentrisme, differEnce / differAnce, trace, dan dencentering.

Differance (Derrida, 2002:45,61) adalah istilah yang diciptakan oleh Derrida tahun 1968 dalam kaitannya dengan pemahamannya mengenai ilmu bahasa Saussure dan antropologi Levi-Strauss. Menurut Derrida, perbedaaan difference dan differance, bahasa kamus baik bahasa Inggris maupun bahasa Perancis dan bahasa dekonstruksi Derrida, tidak dapat diketahui melalui ucapan, melainkan melalui tulisan. Menurutnya, tulisan lebih utama dibandingkan dengan ucapan. Menurut Derrida (Eagleton, 1983:127-128) makna tidak dengan sendirinya hadir dalam suatu lambang. Lambang mempersoalkan sesuatu yang bukan dirinya, lambang mewakili sesuatu yang lain. Makna hadir dalam rangkaian penanda.

Konsep Saussure yang juga didekonstruksi oleh Derrida adalah doktrin hierarki ucapan-tulisan, yang pada dasarnya memandang ucapan sebagai pusat, sedangkan tulisan sebagai non pusat. Menurut Saussure, ucapan lebih dekat dengan pikiran dan perasaan sebab ucapan mengimplikasikan subjek yang berbicara, subjek yang hadir secara serta merta, sedangkan tulisan yang bersifat sekunder, termediasi, grafis dan mewakili.

Menurut Derrida konsep ucapantulisan dapat saja dibalik menjadi tulisanucapan. Ujaran pun adalah sejenis tulisan, ujaran selalu sudah tertulis, dan dengan demikian bahasa pun sudah tertulis. Menurut Rousseau, ucapan merupakan bentuk asal, tulisan merupakan pelengkap bahasa lisan. Di pihak yang lain, Levi-Strauss melukiskan hubungan antara alam dan kebudayaan yang dengan sendirinya sudah tertulis.

Dekonstruksi juga berkembang di Amerika, sebagai aliran yale. Dekonstruksi Amerika, disamping memiliki ciri-ciri tersendiri, sebagai akibat latar belakang sosiokultural. Tokoh-tokoh deonstruksi Amerika diantaranya: Paul de Man, J.Hillis Miller, Geoffery Hartman, dan Harold Bloom. 


Paul de Man

(Eagleton,1983:145;Selden,1986:96) lahir di Belgia, merupakan seorang Filolog dan kritikus sastra. Paul de Man memandang bahwa semua bahasa bersifat metafora, bahasa sastra mendekonstruksi hakikatnya sendiri. Hillis Miller memusatkan perhatian pada dekonstruksi rekaan Goeffery Hartman memusatkan perhatian pada sastra kontemporer, teks-teks injil, dan kritik kebudayaan. Harold Bloom menggabungkan teori trope atau bahasa kias, psikologi Freut dan teks injil.

Model dekonstruksi dalam sejarah dikemukakan oleh Hayden White dalam bukunya Tropics of Discourse (1987). Menurut White, sejarah tidak seratus persen objektif sebab bagaimanapun sejarahwan menyusun cerita kedalam suatu struktur, menceritakan kembali dalam suatu plot.

Perbedaan antara pembaca non dekonstruksi dan dekonstruksi dapat dijelaskan sebagai berikut. Pembaca non dekonstruksi atau pembaca konvensional dilakukan dengan cara menemukan makna yang benar, makna terakhir, yang disebut sebagai makna optimal. Sebaliknya, pembaca dekonstruksi tidak perlu menemukan makna terakhir. Yang diperlukan adalah pembongkaran secara terus menerus, sebagai proses. Dekonstruksi dilakukan dengan cara pemberian perhatian terhadap gejala-gelaja yang tersembunyi, sengaja disembunyikan, seperti ketidakbenaran, tokoh sampingan, perempuan, dan sebagainya.

$$
\text { Umar Junus }
$$

memandang dekonstruksi sebagai persepektif baru dalam penelitian sastra. Dekonstruksi justru memberikan dorongan untuk menemukan segala sesuatu yang selama ini tidak memperoleh perhatian. Memungkinkan untuk melakukan penjelajahan intelektual dengan apa saja, tanpa terikat dengan sutu aturan yang dianggap telah berlaku universal.

Dalam dekonstruksi, pembacaan tak harus dimulai dari awal, ia bisa dimulai dari mana saja. Bahkan Derrida memulai dari sebuah catatan kaki. Dari pembacaan didapati beberapa unit wacana yang mengalami kebuntuan. Dekonstruksi berusaha untuk meruntuhkan paham bahwa suatu karya sastra, baik itu cerita maupun tokohnya hanya mempunyai satu makna dan penilaian yang dominan dengan kebenaran mutlak. Dekonstruksi hadir untuk mewadahi konsep multi-makna serta pemunculan makna dan penilaian baru dengan bukti-bukti yang cukup sebagai pendukung. Sebuah teks selalu memiliki wajah ganda. Ketika kita berpikir mengenai sebuah makna dan menarik kesimpulan dari makna tersebut, seringkali di saat itulah teks menorehkan makna lain yang berbeda dari makna yang telah kita ambil (Al-Fayyadl, 2006:78). Teori Dekonstruksi bisa kita gunakan untuk mengungkap makna dan menarik kesimpulan lain yang selama ini mungkin saja luput dari perhatian kita sebagai pembaca karya sastra. Penelitian yang penulis lakukan bertujuan untuk menunjukkan bahwa makna yang selama ini diyakini tidak sepenuhnya benar, karena ada makna lain yang selama ini belum terungkap. Penggunaan teori Dekonstruksi bertujuan untuk memudahkan penulis mengungkap sisi lain dari tokohtokoh yang ada dalam novel Sengsara Membawa Nikmat. Hal-hal yang selama ini diyakini oleh pembaca sebagai sebuah penilaian tunggal akan diwarnai dengan pembalikkan imej dan penilaian yang dihadirkan sebagai proses kritik terhadap dominasi yang menutupi sisi lain tersebut.

\section{METODOLOGI PENELITIAN}

Metode adalah prosedur atau cara yang digunakan dalam menempuh suatu tujuan tertentu (Suriasumantri, 1996:330). Metode yang digunakan dalam penelitian ini adalah Metode Kualitatif. Metode Kualitatif itu sendiri merupakan suatu metode yang tidak menggunakan prosedur analisis statistik atau cara kuantifikasi lainnya (Moleong, 2010:6). Metode ini mementingkan upaya memahami sikap, pandangan, perasaan, dan perilaku seseorang ataupun sekelompok orang.

Penelitian ini menggunakan metode dan teknik analisis teks untuk memahami karakter setiap tokoh yang ada dalam cerita sengsara membawa nikmat. Penelitian ini 
menggunakan teori Dekonstruksi yang digagas oleh Jacques Derrida, dan Strukturalisme sebagai teori pendukung dalam menguraikan watak tokoh. Dekonstruksi adalah sebuah cara membaca yang dimulai dengan pencatatan (penelusuran) secara hierarki, kemudian diteruskan dengan membalikkannya, dan akhirnya menentang pernyataan hierarki (Tuloli, 1979:58).

\section{HASIL DAN PEMBAHASAN \\ Dekonstruksi Terhadap Tokoh Dalam Novel Sengsara Membawa Nikmat}

Dalam memahami karya sastra kita sering melakukan pembacaan denotative yang membuat kita terpaku hanya pada satu pemahaman. Makna lain seringkali tidak terpikirkan karena mungkin merupakan makna sekunder yang dikehendaki oleh pengarang. Akan tetapi, keberadaan makna lain itu sudah membuktikan bahwa pemahaman terhadap sebuah teks tidak pernah tunggal dan menyimpan potensi penafsiran baru yang kerap kali tak terduga (Al-Fayyadl, 2006:78). Potensi inilah yang penulis angkat ke permukaan dengan harapan pembaca tidak hanya meyakini satu makna yang dipahami melalui pemaknaan denotatif yang hanya terlihat dari permukaan teks.

Penggalian makna dan penafsiran baru dilakukan dengan menggunakan teori dekonstruksi yang bertujuan untuk merusak atau menganggu kestabilan teks. Dekonstruksi menggugat modus pemaknaan yang terpusat dan cenderung bulat seperti yang mungkin diinginkan oleh teks atau yang sengaja dimunculkan secara terangbenderang oleh hubungan logis dari teks itu. Logika permainan yang dibentuk oleh pembacaan dekontruktif akan menunjukkan bahwa sebuah teks dapat saja menyangkal apa yang sudah ditegaskannya (Al-Fayyadl, 2006:82). Dalam hal ini penulis bermaksud menguak sebuah makna baru melalui tokoh dalam cerita. Dalam analisis ini penulis membongkar sisi lain tokoh dalam novel Sengsara Membawa Nikmat Membongkar tokoh tidak hanya terpaku pada watak tokoh, tetapi dapat juga dilakukan dengan melihat fungsi tokoh dalam menentukan jalan cerita.

Dalam membongkar tokoh, penulis sekaligus melebur batas - batas tokoh. Tokoh dilihat sebagai sebuah peran tanpa melihat besar/tidak nya peranan tokoh. Dengan kata lain, setelah dilakukan dekonstruksi maka tidak ada lagi tokoh mayor dan minor dan tidak ada protagonis dan antagonis lagi.

Berdasarkan fungsinya tokoh tambahan dan tokoh sentral dilebur ke dalam satu sebutan yaitu tokoh. Tokoh tambahan yang selama ini dianggap tidak terlalu penting bisa menjadi tokoh yang sangat penting, untuk menguatkan alasan maka dimunculkan kemungkinan baru jika tokoh tersebut tidak ada dalam cerita. Begitupun berdasarkan wataknya, penulis menampilkan watak-watak yang selama ini tidak di sorot pada setiap tokoh dalam novel.

\section{Sisi Lain Tokoh \\ Sifat Buruk Pada Tokoh Midun}

Midun adalah tokoh yang diceritakan sebagai orang alim, baik, sopan, dan disukai oleh orang banyak. Tetapi jika kita membaca ulang dan memainkan logika akan terlihat sifat-sifat yang tidak patut ditiru dari tokoh tersebut. Keburukan yang dimiliki Midun terlihat dari dialog serta tindakan yang dilakukannya. Penulis menemukan beberapa sifat buruk yang ada pada tokoh Midun:

\section{a) Tidak Berani Mempertahankan Diri}

Midun adalah sosok yang baik di mata orang banyak. Ia juga sudah mendapat pengajaran dari Haji Abbas, bapaknya yang termasyhur sebagai jago silat dan ahli ilmu agama. Namun Midun tetap tidak berani menghadapi Kacak yang selalu mengganggu dan menekan Midun dengan berbagai cara. Padahal jika Midun berani berhadapan dengan Kacak besar kemungkinan ia akan menang dan orang kampung juga akan membelanya. Ketika menjalani hukuman di Padang pun juga demikian. Midun yang sering diantarkan nasi oleh Halimah dan pembantunya juga ditindas oleh mandur Saman yang rakus. Mandur Saman sendiri 
sebenarnya takut kepada Midun, karena sudah dilihatnya bagaiman ketangkasan anak muda itu dan juga kedekatan Midun dengan Turigi, orang yang paling ditakuti dan disegani di dalam penjara ketika itu. Nasi cukup dengan lauk pauknya yang diantarkan untuk Midun selalu diberikannya kepada mandur Saman sebab Midun takut hukumannya akan bertambah seperti ancaman mandur Saman kepadanya.

\section{b) Buta Huruf}

Midun adalah sosok yang buta terhadap huruf latin. Ia hanya bisa membaca dan menulis dengan huruf arab yang lazim dikenal sebagai tulisan surau. Memang pada zaman penjajahan Belanda buta akan huruf latin adalah hal yang biasa karena banyak masyrakat Indonesia yang tidak bersekolah. Namun kekurangan ini membuat Midun tidak bisa melakukan sesuatu yang memerlukan kemampuan membaca huruf latin seperti pengurusan surat pas untuk dirinya dan Halimah agar bisa berlayar ke pulau jawa. Hal ini terlihat pada kutipan:

....'Bagi saya gelap perkara surat pas itu. Sebab itu saya harap Bapaklah yang akan menolong perkara itu." (Sati: 122)

Kebutaannya akan huruf latin juga memeiliki dampak lain bagi diri Midun. Karena tidak bisa baca tulis dalam huruf latin ia dengan gampang ditipu oleh seorang saudagar keturunan arab. Midun yang hanya meminjam uang sejumlah f 250,- diminta untuk membayar dengan jumlah dua kali lipat. Merasa dirinya tertipu, Midun tidak mau membayar utangnya kepada saudagar itu dan akhirnya Midun diadukan ke polisi. Karena saudagar arab itu memiliki bukti berupa surat utang, Midun akhirnya kalah dalam persidangan dan kembali ditahan dalam penjara di Glodog. Hal ini terlihat dalam kutipan:

Terperanjat sungguh Midun mendengar perkataan Syekh Abdullah itu. Ia tahu uang yang dipinjamnya, Cuma f 250,- tiba-tiba sekarang menjadi f 500,- ? Maka ia pun berkata dengan cemasnya, katanya "Berapa Tuan? F 500,-? Mengapa jadi 500,-?, padahal saya terima uang dari Tuan Cuma f 250,-?"
"Ya, f 500,-!" ujar Syekh Abdullah pula. "Midun mesti bayar f 500,- sekarang, sebab sekian ditulis dalam surat-utang." (Sati: 156)

\section{Suka Bergunjing}

Bergunjing adalah kebiasaan membicarakan aib atau keburukan orang lain. Kebiasaan ini biasanya dimiliki oleh kaum perempuan. Namun tokoh Midun ternyata juga suka membicarakan keburukan orang lain seperti terlihat pada dialog antara tokoh Midun dan Maun:

"Baik, saya pun amat suka berniaga," jawab Maun . . . Jika pandai menjalankan perniagaan, memang lekas benar naiknya. Tapi jatuhnya mudah pula. Lihatlah Baginda Sutanitu! Dari sekaya-kayanya jatuh jadi semiskin-miskinnya. Sekarang pikirannya tidak sempurna lagi."

"Benar katamu itu. Karena Baginda Sutan sangat tamak akan uang dan sangat kikir pula, ia dihukum Tuhan. Boleh jadi ia berniaga terlampau banyak mengambil untung, lalu dimurkai Allah. Kekikirannya jangan dikata lagi. Bajunya baju hitam yang sudah berkilat lehernya, karen tidak bercuci. Baunya pun tidak terperikan busuknya. Uang seduit dibalikbaliknya dulubaru dibelanjakan." (Sati: 68)

Dari kutipan di atas terlihat bahwa Midun dan Maun sedang membicarakan keburukan Baginda Sutan. Perilaku yang demikian biasa disebut bergunjing yang merupakan salah satu kebiasaan yang buruk. Selain menimbulkan dosa, kebiasaan ini juga bisa menimbulkan konflik dalam masyarakat karena adanya perubahan informasi dari mulut ke mulut.

\section{Lancang}

Kelancangan Midun terlihat dari sikapnya yang secara terang-terangan menyalahkan orang lain di pasar malam. Midun sedikitpun tidak memikirkan kalau pernyataannya itu membuat orang lain merasa marah, malu, atau tersinggung. Setelah melontarkan perkataan Midun langsung pergi meninggalkan lawan bicaranya karena ia melihat wajah orang itu tiba-tiba berubah, 
mungkin karena menahan emosi. Sikap Midun yang demikian terlihat pada kutipan:

...Benci benar midun mendengar perkataan itu, hampir-hampir tak dapat ia menahan hati. Tiba-tiba terlanjur juga, lalu berkata, "Tuhan yang dapat menetukan berbahagia atau tidaknya untung nasib seseorang, tetapi batu ini ...."

Midun dan Maun segera berjalan ke lepau nasi, karena ketika hendak berkata lagi, dilihatnya muka yang punya batu berubah sekonyongkonyong. (Sati: 73)

Sikap Midun yang terang-terangan ini merupakan tindakan yang benar jika dipandang dari kacamata agama. Namun jika dilihat dari adat sopan santun Minangkabau yang mengajarkan "kalamak dek awak, katuju dek urang" sikap ini merupakan sebuah kesalahan. Apa yang dikatakan Midun memang benar, tapi hal itu dikatakannya di depan orang banyak dan membuat malu si pemilik batu. Seharusnya Midun melakukan pembicaraan secara pribadi dan tidak mempermalukan pemilik batu itu di hadapan orang banyak.

\section{Selalu Bergantung pada Orang Lain}

Midun adalah tokoh yang tidak bisa maju tanpa bantuan orang lain. Semua yang telah diraihnya tidak terlepas dari bantuan orang lain. Bisa disimpulkan jika tidak ada orang lain, maka kehidupan Midun akan begitubegitu saja, tidak akan ada perubahan dan perkembangan. Midun merupakan tipe yang tidak mandiri, kurang memotivasi diri dan tidak berinisiatif. Jalan kesuksesan Midun selalu bertumpu pada uluran tangan orang lain. Ia menunggu nasib baiknya dibentuk dan diarahkan oleh tokoh-tokoh mulai dari kehidupan Midun di kampung, dalam penjara, keluar dari penjara, dan di Betawi. Selalu ada satu orang yang menopang dan membantu kehidupannya.

Midun memiliki ketergantunga terhadap banyak orang, diantaranya:

1. Ketergantungan Midun pada Maun, Haji Abbas, dan Pandeka Sutan ketika Midun masih tinggal di kampungnya.

2. Ketergantungan Midun pada Tokoh Turigi ketika ia dipenjara di Padang.
3. Ketergantungan Midun pada nenek suruhan Halimah ketika Midun hendak menolong Halimah dan merahasiakan tempatnya bersembunyi.

4. Ketergantungan Midun pada Pak Karto saat Midun hendak menolong Halimah sampai keberangkatannya ke pulau Jawa.

5. Ketergantungan Midun pada Syekh Abdullah Al-Hadramut dalam memperoleh pekerjaan ketika ia baru sampai di Betawi.

6. Ketergantungan pada Mas Sumarto yang telah mengajarkan Midun membaca dan menulis huruf latin saat ia dipenjara di Glodok.

7. Ketergantungan Midun pada Tuan Hoofdcommissaris yang telah memberi Midun pekerjaan yang layak hingga membantu Midun dalam mengurus

8. kepindahannya ke kampung halamannya.

\section{Tidak Tahu Terima Kasih atau Tidak Membalas Guna}

Selain Midun banyak bergantung dan berhutang budi kepada orang lain ternyata ia juga merupakan orang yang tidak tahu terimakasih. Hal ini terlihat dari:

- Midun tidak berpamitan dan berterimakasih kepada Mas Sumarto, padahal Mas Sumartolah yang mengajarinya baca-tulis sehingga ia dipekerjakan di kantor Tuan Hoofdcommissaris.

- Midun tidak menemui Turigi di penjara ketika ia telah kembali ke Padang meskipun ia tahu kalau Turigi dihukum seumur hidup, padahal Turigi telah menyelamatkan nyawa Midun dari pengeroyokan semasa Midun menjalani hukuman di Padang.

- Midun tidak menemui Nenek yang dulu menjadi suruhan Halimah, padahal Nenek itulah satu-satunya penghubung antara tokoh Midun dan Halimah ketika mereka akan meninggalkan kota Padang.

\section{Tidak Ingat kepada Orang Tua}

Di Minangkabau, bakti anak terhadap orang tua adalah hal yang sangat penting. Sekalipun di Minangkabau ada tradisi 
marantau, namun kepulangan ke kampung halaman adalah hal yang selalu diharapkan. Ada suatu kebiasan yang dianggap kurang baik yang dikenal dengan sebutan marantau cino; yaitu merantau tanpa ingat kembali ke kampung halaman. Seseorang merantau bertujuan untuk merubah hidupnya dan kemudian kembali ke kampung halaman dengan kondisi yang lebih baik. Midun, berangkat merantau bukan karena mengikuti tradisi, melainkan karena keadaan dan kesempatan. Karena kegelisahan hatilah ia tidak kembali ke Bukit tinggi saat ia bebas dari penjara. Namun, dalam hal ini terdapat satu hal yangagak janggal pada keputusan Midun. Ia meninggalkan ranah Minang, ia tidak bertatap muka dengan kedua orangtuanya. Kepergiannya hanya disampaikan pada sepucuk surat, hal ini menimbulkan duka bagi kedua orangtuanya, terutama Bapaknya. Midun sama sekali tidak mengingat hal itu saat ia mengambil keputusan. Alasannya pergi pun sama sekali tidak bijak. Tergambar dalam kutipan:

"Hati Midun pun agak malas pulang, mengingat permusuhannya dengan Kacak." (Sati: 115)

Saat berada di tanah Jawa pun, Midun sama sekali tidak ingat kepada kedua orangtuanya. Sebab, tidak sekalipun ia mengirim surat untuk sekedar bertukar kabar atau sekedar menanyakan keadaan kedua Ibu-bapaknya. Bahkan, ketika ia sudah mempunyai kehidupan yang baik dan hendak melangsungkan pernikahan, jangankan undangan, sepatah katapun dari Midun yang bermaksud memberi tahu ayah-ibunya sama sekali tidak ada. Padahal, saat itu ia sudah mempunyai uang dan sedikit pengetahuan, seharusnya Midun bisa berkirim surat ke kampung halamannya.

Melakukan Perkawinan yang Tidak Ideal

Minangkabau merupakan salah satu daerah di Indonesia yang sangat menjunjung tinggi adat-istiadat, termasuk dalam hal perkawinan. Dalam persepsi masyarakat Minangkabau, pernikahan yang ideal adalah pernikahan yang dilakukan dengan prosesi agama dan diiringi dengan prosesi adat yang lazim disebut baralek. Dalam masalah perkawinan, bagi masyarakat Minang, sedapatnya calon suami/istri dari anaknya berasal dari daerah yang sama, atau setidaknya samasama orang Minang. Memiliki asal-usul dan suku atau kaum yang jelas. Menurut alam pikiran orang Minangkabau, perkawinan yang paling ideal adalah perkawinan antara keluarga dekat, seperti perkawinan antara anak dan kemenakan (Navis, 1984: 194) Lebih lanjut A. A. Navis mengatakan "perkawinan dengan orang luar, terutama mengawini perempuan luar dipandang sebagai perkawinan yang bisa merusak struktur adat mereka. Pertama-tama karena anak yang lahir dari perkawinan itu bukanlah suku bangsa Minangkabau (Navis, 1984: 19). Anak yang lahir dari perkawinan dengan perempuan yang berasal dari luar Minangkabau akan dianggap sebagai anak yang tidak bersuku karena masyarakat Minangkabau sendiri menganut sistem kekerabatan matrilineal. Garis keturunan ditarik dari pihak ibu. Jika ibunya tidak memiliki suku, maka anaknya pun juga akan demikian.

Untuk mengatasi problem seperti ini masyarakat Minangkabau mengenal adanya sistem malakok, yaitu mencarikan suku bagi orang yang berasal dari luar Minangkabau. Hal ini tidak dijumpai dalam cerita, sehingga sampai akhir cerita sosok Halimah masih merupakan orang asing, bukan suku bangsa Minangkabau. Seharusnya Midun yang saat itu sudah menjadi asisten demang di kampungnya melakukan prosesi malakok agar istrinya Halimah dan anaknya Basri bisa memperoleh suku dan kedudukan yang sama dengan masyarakat Minangkabau lainnya. Kemudian jika dilihat dari prosesi adat, perkawinan Midun dan Halimah juga tidak sesuai dengan adat yang berlaku di Minangkabau. Bagi masyarakat Minangkabau perkawinan bukan hanya penyatuan individu dalam sebuah rumah tangga, namun juga merupakan penyatuan dua keluarga besar. Perkawinan yang dilakukan Midun tidak sesuai dengan prosesi yang lazim dilakukan di Minangkabau, ia 
tidak memberitahu dan tidak meminta izin untuk melakukan perkawinan kepada keluarga besarnya. Hal ini menyebabkan keluarga Midun tidak kenal dengan keluarga Halimah. Hingga akhir cerita, ibu kandung Midun hanya tau menantu dan cucunya tanpa mengetahui siapa mertua dari anaknya.

\section{Sifat Buruk Pada Tokoh Halimah}

Halimah seorang wanita yang terihat lemahlembut serta tegar, ia menjalani kehidupan yang cukup sulit juga. Di balik kelemahlembutan serta sifat tegarnya itu, Halimah juga mempunyai dua sifat yang kurang baik apabila melekat pada seorang perempuan, yaitu:

\section{Tidak Bisa Mandiri}

Seperti halnya Midun, ternyata tokoh Halimah juga tidak bisa mandiri dan selalu bergantung pada orang lain. Halimah berasal dari Bogor, namun ia sudah lama menetap di Padang, malahan ia adalah orang berpendidikan juga. Seharusnya ia tahu tempat mana yang harus ia tuju dan apa yang harus dilakukannya untuk menyelamatkan hidupnya. Tapi apa yang terjadi dalam cerita sama sekali berbeda. Halimah bergantung pada nenek suruhannya dalam hal keselamatan hidupnya. Ketergantungan lainnya adalah terhadap tokoh Midun dan Pak Karto yang juga ikut membantunya untuk meninggalkan kota padang dan kembali ke Bogor.

\section{Terlalu Gampang Percaya Kepada Orang Lain}

Halimah adalah tipe orang yang terlalu gampang percaya kepada orang lain. Ia tidak menimbang-nimbang dahulu, siapa orang yang baru dikenalnya itu, bagaimana wataknya, dan seperti apa keadaan hidupnya. Kelemahan Halimah ini pada kenyataannya mendatangkan kesulitan kepada diri Halimah sendiri, hal itu terbukti saat ia kehilangan ibunya dan bapak tiri Halimah mencoba merayu dirinya, Halimah percaya saja kepada orang Tionghoa yang baru dikenalnya. Orang itu berpura-pura ingin menolong Halimah, dengan polosnya ia ikut ke rumah Tionghoa itu, sesampai disana, Halimah baru tahu bahwa dirinya hendak diperkosa oleh orang Tionghoa tersebut. Andai saja Halimah tidak terlalu mudah percaya, mungkin ia tidak akan terjerumus ke dalam masalah yang demikian. Kedua, Halimah sangat menaruh percaya kepada Midun, meskipun hal ini tidak mendatangkan petaka, namun tetap saja Halimah terlalu mudah mempercayai orang lain. Ia bahkan menyerahkan keselamatan hidupnya kepada Midun, seorang bekas hukuman yang baru dikenalnya. Seandainya Midun merupakan orang yang jahat, tentu ia dapat memperlakukan Halimah sesuka hatinya, bahkan mungkin Halimah bisa saja ditipu dan tidak diantarkan ke Bogor, tetapi dibawa ke daerah lain atau mungkin dijual. Jika Halimah tidak mudah percaya kepada orang lain hal itu akan menimbulkan beberapa kemungkinan, diantaranya: (1) Halimah tidak akan berkenalan dengan Midun. (2) Kalung berlian yang ditemukan Midun bisa jadi tidak membawa keberuntungan, namun justru membawa petaka bagi diri Midun karena jika tidak gampang percaya kepada orang lain besar kemungkinan Halimah justru akan menuduh Midun yang telah mengambil kalung berliannya. Bapaknya yang merupakan seorang belanda tentu saja akan melakukan sesuatu yang buruk jika ia mengetahuinya. (3) Halimah dan Midun tidak akan berangkat ke pulau Jawa dan mereka tidak akan bersatu dalam sebuah rumah tangga.

\section{Sifat Baik Pada Tokoh Kacak}

Kacak yang selalu identik dengan kejahatan dan semua sifat buruknya ternyata memiliki sisi lain. Ada sifat-sifat baik yang dapat ditiru darinya. Sifat-sifat baik kacak antara lain adalah sebagai berikut:

\section{a. Menjujung Tinggi Harga Diri}

Orang Minang memiliki prinsip bialah mati bakalang tanah daripado iduik bacamin bangkai. Secara sederhana ini menunjukkan karakter orang minang yang tidak mau dipermalukan atau selalu menjujung tinggi harga dirinya. Kacak menganggap bahwa 
Midun sudah mempermalukannya. Pertama di merasa dipermalukan di depan orang banyak saat permainan sepak raga. Kedua, ia merasa dipermalukan saat istrinya hanyut di sungai dan ditolong oleh Midun. Hal ini diperparah lagi karena saat Midun menyelamatkannya istri kacak berada dalam keadaan tanpa kain. Midun yang bukan mukhrimnya telah menyentuh istri Kacak. Walaupun bermaksud menolong, namun Kacak tetap merasa bahwa istrinya tidak boleh disentuh oleh orang lain, apalagi dalam keaadaan tanpa busana. Kacak menilai perbuatan Midun sebagai pelecehan terhadap harga dirinya. Dan untuk mempertahankan harga dirinya tersebut kacak berani bertentangan dengan Midun walaupun pada akhirya ia kewalahan menghadapi Midun. Sikap Kacak yang seperti ini patut dipuji, karena demi mempertahankan harga dirinya ia rela melakukan apa saja. Jika Kacak tidak memiliki sikap yang demikian, kemungkinan ia dan Midun tidak akan terlibat perseteruan yang pada akhirnya menentukan jalan cerita. Jika mereka tidak berseteru tentu saja Midn akan tetap berada di kampong halamannya. Hidupnya dan juga pola pikirnya akan tetap begitu-begitu saja, kehidupannya tidak akan memiliki kemajuan dan perkembangan.

\section{Pandai Memanfaatkan Situasi}

Pandai memanfaatkan situasi adalah kata yang cocok untuk menggambarkan jalan pikiran Kacak yang licin dan banyak akal. Salah satu contoh dari perbuatan Kacak yang pandai memanfaatkan situasi adalah kejadian manakala ia mempersiapkan sebuah siasat bagi Midun pada acara pasar malam dan pacuan kuda di Bikittinggi. Ia memanfaatkan keramaian itu sebagai waktu untuk membinasakan Midun, agar orang kampung tidak semata - mata curiga pada dirinya sebagai pelaku kejahatan yang direncanakan tersebut. Kedua, hal ini juga dapat dilihat pada kedudukan mamak Kacak sebagai Tuanku Laras. Selaku kemenakan dari orang yang berkuasa di kampung tersebut Kacak merasa ia dapat melakukan apapun. Ia merasa mempunyai pegangan atau jaminan atas keselamatan dirinya, apabila ia membuat perkara dengan orang lain, khususnya Midun. Seandainya ia tidak pandai memanfaatkan situasi, mungkin Kacak tidak akan melihat acara tersebut sebagai kesempatan yang baik. Bisa jadi, ia akan terus-menerus menyerang Midun saat di kampungnya sendiri dan dengan gampang orang kampung dapat menduga bahwa Kacak adalah satu-satunya tersangka. Selanjutnya, ia juga menjadikan mamaknya Tuanku laras sebagai tameng bagi dirinya.

\section{Optimis}

Kacak adalah orang yang mempunyai pendirian dan keyakinan yang kuat dan keras. Hal ini merupakan salah satu bentuk sikap optimis dari seorang Kacak. Ia selalu bertekad akan mengalahkan Midun. Dalam setiap upayanya ia selalu yakin akan dapat mengalahkan Midun. Buktinya ia tidak segan-segan untuk selalu menantang Midun dimanapun mereka berjumpa. Hal kedua yang menjadi bukti keoptimisan Kacak adalah ia selalu yakin bahwa ia akan selamat dan bebas dari segala ancaman hukuman apabila ia membuat perkara dengan Midun karena ada mamaknya Tuanku Laras yang bisa melindunginya. Hal itu selalu menjadi kekuatan bagi Kacak untuk selalu mensiasati Midun. Jikalau Kacak tidak bersikap optimis, mungkin ia sudah akan menyerah saat pertama kali ia kalah menghadapi Midun di lapangan sepak raga. Kemudian, jika saja kacak tidak yakin bahwa jabatan mamaknya dapat menjadi pegangan bagi Kacak, mungkin ia tidak akan berani menjebak Midun hingga sedemikian rupa.

\section{Sifat Buruk Pada Tokoh Pak Midun}

Pada awal cerita, Pak Midun diperkenalkan sebagai seorang yang arif bijaksana dan berwawasan luas sebab ia sudah cukup lama merantau, sudah banyak merasakan asammanis kehidupan. Namun, jika kita perhatikan dan telaah dengan seksama, sesungguhnya Pak Midun merupakan orang yang kurang arif, hingga membinasakan diri sendiri. Hal ini dapat dilihat dari pernyataan Haji Abbas: 
"Sudah setua ini Pak Midun, belum juga tah akan ujud keputusan itu", ujar Haji Abbas. "Kilat beliung sudah ke kaki, kilat cermin sudah ke muka. Anak kita masa ini dalam bahaya. Kita harus beringat-ingat". (Sati: 53) Selain itu ketidakarifan Pak Midun juga terlihat pada saat ia jatuh sakit memikirkan Midun, hingga akhirnya meninggal dunia. Seharusnya, jika ia benar-benar arif, ia tidak perlu memikirkan Midun sedemikian rupa, sebab anak nya itu sudah dewasa, pandai beladiri, dan juga baik akhlaknya. Ia sudah cukup bekal untuk pergi meninggalkan rumah. Dengan menyusahkan dirinya sendiri dengan pikiran tentang Midun, secara tidak langsung Pak Midun sudah menyusahkan anak-anaknya yang lain. Akan lebih baik jika Pak Midun bersabar menunggu Midun dan tetap berusaha untuk kehidupan keluarga dan anaknya yang masih di kampung.

\section{Sifat Buruk Pada Tokoh Datuk Paduka Raja}

Datuk Paduka Raja adalah mamak Midun, ia merupakan sosok mamak yang tau dengan ereng dan gendeng serta menyayangi kemenakannya. Sebagai seorang mamak sekaligus penghulu dalam kaumnya Datuk Paduka Raja berkewajiban membela dan melindungi kepentingan kaumnya. Hal yang demikian sudah dijalankannya, namun di balik semua itu dia merupakan sosok yang licik. Kelicikan Datuk paduka Raja terlihat pada saat dia berusaha mempertahankan harta pusaka kaumnya ketika tokoh Sutan Manindih yang merupakan kemenakan Pak Midun berusaha meminta agar harta peninggalan Pak Midun diberikan kepadanya. Datuk Paduka Raja sebenarnya sudah tahu siapa yang berada di balik semua itu. Untuk mengurangi kerugian ia sengaja memperpanjang urusan walaupun akhirnya dia akan tetap kalah.

Perebutan harta pusaka itu sengaja dibawa ke persidangan. Hasilnya, pihak keluarga Pak Midun tetap memenangkan persidangan. Meskipun menang, tapi pihak keluarga Pak Midun tidak mendapatkan harta pusaka sesuai jumlah yang seharusnya karena sebagian besar harta peniggalan Pak Midun telah habis untuk biaya persidangan. Secara sederhana dapat disimpulkan bahwa sosok Datuk Paduka Raja adalah orang yang licik. Datuk Paduka Raja memiliki prinsip "jika dia tidak bisa mempertahankan sesuatu, maka orang lain juga tidak boleh mendapatkannya".

\section{SIMPULAN}

Pengkajian secara dekonstruksi telah melebur batas yang selama ini tercipta antara tokoh protagonis-antagonis dan tokoh utamatambahan. Setiap tokoh adalah tokoh, tidak ada pertimbangan tokoh protagonis dan antagonis. Tokoh protagonis ternyata juga memiliki sisi negatif, dan sebaliknya tokoh antagonis ternyata juga memiliki sisi positif yang patut dicontoh. Dengan kata lain, tokoh dalam novel sengsara membawa nikmat juga seperti kita (manusia nyata) yang memiliki sifat baik dan buruk, kelebihan dan kekurangan.

Begitu juga dengan tokoh utama dan tokoh tambahan. Kita tidak bisa mengabaikan tokoh walaupun tokoh tersebut tidak selalu dimunculkan dalam cerita. Sekecil apapun peran tokoh dalam cerita ia tetap ikut membangun cerita tersebut. Jika salah satu tokoh dihilangkan akan muncul kemungkinan baru yang akan merubah jalan cerita. Kemungkinan baru juga akan muncul jika salah satu tokoh melakukan tindakan yang berbeda dari apa yang diceritakan.

\section{DAFTAR PUSTAKA}

Aji, Wiranto. 2011. "Teori Dekonstruksi dalam Novel." (Online) Dalam http://wirantoaji.blogspot.com/2011/12 /teori-dekonstruksi-derrida-dalamnovel.html?m=1.

(Diakses pada tanggal 10 Juni 2018).

Fauzan. 2009. "Dekonstruksi terhadap Keturunan Darah Biru" (Online) Dalam (http://staff.undip.ac.id/sastra/fauzan/2 009/07/22/dekonstruksi-terhadap-figurketurunan-darah-biru/).

(Diakses pada tanggal 10 Juni 2018). 